\title{
Pemanfaatan Limbah Kulit Talas Bogor (Colocasia Esculenta) Sebagai Sumber Energi Alternatif Bioetanol
}

\author{
Lily Arlianti ${ }^{1)}$ Ismi Nurlatifah $^{2)}$ Destrina Jessica Wulandari ${ }^{3)}$ Hurin Kamilah ${ }^{4)}$ Tena Riszki \\ Agusti $^{5)}$ Mistyawati Eka Agustina ${ }^{6)}$ Ida Agniatul Mamnuah ${ }^{7)}$
}

*Jurusan Teknik Kimia, Fakultas Teknik,Universitas Islam Syekh Yusuf, Jl. Mulana Yusuf No.10 Tangerang Banten 15118, Indonesia

1) larlianti@unis.ac.id

2) isminurlatifah@unis.ac.id

\begin{abstract}
Abstrak. Penanggulangan limbah organik baik limbah domestik maupun limbah industri menjadi suatu hal yang sangat penting untuk dikembangkan karena jumlah limbah atau sampah organik sejalan dengan pertumbuhan jumlah penduduk di Indonesia. Salah satu limbah organik yang banyak dihasilkan dari produksi makanan adalah kulit talas Bogor. Limbah kulit talas ini kami konversi menjadi bioetanol dengan metode fermentasi menggunakan ragi tape yang mengandung saccharomyces cereviceae dengan variasi lama fermentasi 4,6,8,10 dan 12 hari. Hasil fermentasi kemudian dipisahkan dengan metode destilasi dan didapatkan berat jenis destilat $0,8483 \mathrm{gr} / \mathrm{mL}$. Dari penelitian ini didapatkan destilat bioetanol sebanyak $79 \mathrm{~mL}$ dengan yield 14,68\%. Dengan demikian limbah kulit talas memiliki potensi untuk konversi biomassa menjadi bioetanol yang merupakan salah satu bahan bakar alternative yang ramah lingkungan.
\end{abstract}

Kata kunci: limbah kulit talas Bogor, fermentasi, bioetanol

Abstract.[ Utilization of Bogor Taro Skin Waste (Colocasia Esculenta) As an Alternative Energy Source of Bioethanols] The handling of organic waste both domestic waste and industrial waste is a very important thing to be developed because the amount of waste or organic waste is in line with the growth of the population in Indonesia. One of the many organic wastes produced from food production is Bogor taro skin. We convert taro skin waste into bioethanol by fermentation method using yeast tape containing saccharomyces cereviceae with long fermentation variations 4,6,8,10 and 12 days. The results of fermentation were then separated by a distillation method and obtained by the specific gravity of distillate $0.8483 \mathrm{gr} / \mathrm{mL}$. From this study, $79 \mathrm{~mL}$ bioethanol distillate was obtained with a yield of $14.68 \%$. Thus taro skin waste has the potential to convert biomass into bioethanol which is one of the alternative fuels that is environmentally friendly.

Keywords: Bogor taro skin waste, fermentation, bioethanol

\section{Pendahuluan}

Berkurangnya sumber energi fosil di Indonesia menimbulkan masalah krisis dibidang energi. Hal ini dapat dilihat dengan meningkatnya harga bahan bakar minyak yang berakibat pada melambatnya pertumbuhan ekonomi karena berkurangnya daya beli masyarakat dan kenaikan harga komoditas terutama bahan pokok. Oleh karena itu Indonesia harus mencari bahan bakar alternatif yang bersifat dapat diperbaharui seperti bioetanol yang berbahan dasar nabati.
Menjamin kelangsungan pengembangan BBN (Bahan Bakar Nabati) yang dapat diperbahatui (renewable) di Indonesia, pemerintah telah menetapkan berbagai kebijakan yang meliputi : PP no.5 tahun 2006 tentang Kebeijakan energi Nasional, Inpres no. 1 tahun 2006 tentang penyediaan dan pemanfaatan bahan bakar nabati (biofuel) sebagai bahan bakar lain, Kepres no.10 tahun 2006 tentang pembentukan tugas tim nasional percepatan pemanfaatan 
BBN untuk mengurangi kemiskinan dan pengangguran (Timnas $\mathrm{BBN}$ ) serta Permen ESDM no. 51 tahun 2006 tentang persyaratan dan pedoman izin usaha niaga BBN (Biofuel) sebagai bahan bakar lain.

Ditargetkan Indonesia mampu mensubtitusi minyak solar dengan biodiesel sebayak 5\% pada 2025. Bioetanol diharapakan dapat mensubtitusi bensin di 5\% pada tahun 2025. Saat ini sudah dikembangkan pembuaatan bioethanol dari berbagai macam sumber seperti singkong, kulit singkong, kulit pisang, bonggol jagung, kulit nanas, kulit durian, kulit coklat dan sebagainya. Hal ini cukup menggembirakan walaupun bioethanol ini belum diproduksi secara besar-besaran. Masih banyak sumber -sumber bioethanol lain yang dapat dikembangkan karena Indonesia adalah negara agrarian dan memiliki hutan yang masih luas.

Metode pembuatan bioethanol yang berkembang saat ini adalah dengan metode fermentasi hidrolisis dan feremnentasi syngas. Fermentasi secara hidrolisis adalah perusakan selulosa dan hemiselulosa pada bahan baku kemudian difermentasi dengan ragi sehingga dihasilkan bioetanol. Metode ini merupakan metode fermentasi langsung pada bahan baku. Saat ini sudah diprosuksi secara besar-besaran di Amerika Serikat bioetanol dari jagung. (Devarapalli dan Atiyeh, 2015). Fermentasi Syrtas merupakan proses konversi tidak langsung untuk mem produksi alkohol, asam organik dan produk lainnya. Tidak seperti fermentasi hidrolisis proses, fermentasi ini disebut sebagai fermentasi tidak langsung karena bahan baku tidak langsung diumpankan ke fermentor. Bahan baku pertama kali digasifikasi menjadi syngas, yang kemudian dibersihkan dan didinginkan ebelum dimasukkan ke dalam fermentor untuk. Bahan baku berbasis non-makanan seperti residu pertanian, limbah padat kota, tanaman energi dan batubara bisa digasifikasi untuk menghasilkan syngas. Syngas merupakan campuran gas $\mathrm{CO}, \mathrm{CO}_{2}$ dan $\mathrm{H}_{2}$ kemudian campuran gas ini yang difermentasi menggunakan mikroorganisme seperti
C.acetum, Acetobacterium woodii, C. anithogenum dan C.ragsdalei untutk memproduksi alkohol (Devarapalli dan Atiyeh, 2015).

Talas bogor memiliki klasifikasi toksonomi berasal dari Arum family, genus Colacasia Schott dan species Colocasia esculenta. Beberapa manfaat talas bila kita mengkonsumsinya untuk kesehatan adalah sebagai sumber energi, sehat unuk jantung dan pencernaan, membantu menjaga tekanan darah, meningkatkan sistem imun tubuh, anti aging dan sebagainya.

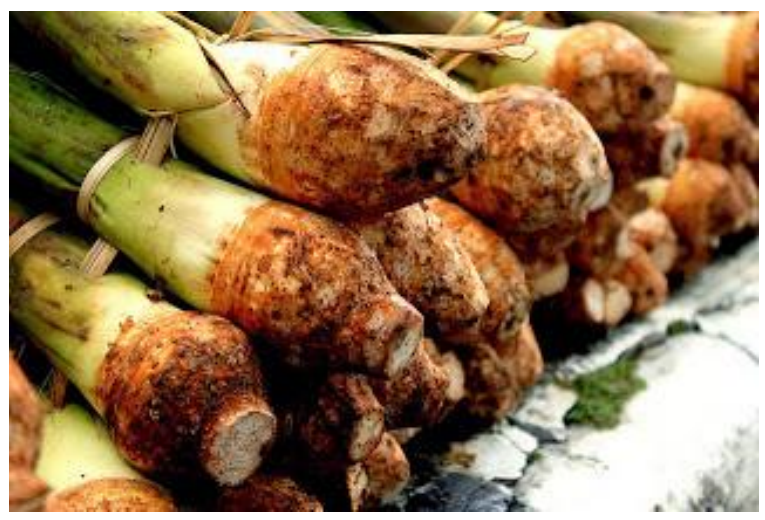

Gambar 1. Talas Bogor

Kandungan kimia dari kulit talas adalah zat pati, protein, lemak, abu, serat dan logam-logam. Zat pati ini yang akan kita fermentasi menjadi bioetanol. Terdapat lima jenis talas yang berkembang di Indonesia saat ini yaitu

talas bogor ,talas kimpul,,talas banten ,talas ketan hitam, talas semir dan talas sutera

\section{Metodologi dan Pembahasan}

Pembuatan bioethanol dari limbah kulit talas bogor ini dilakukan dalam lima tahap yaitu tahap preparasi, tahap delignifikasi, hidrolisis, fermentasi dan distilasi.

\subsection{Preparasi dan Delignifikasi}

Kulit talas bogor dicuci sampai bersih dengan air kemudian jemur kulit talas yang sudah bersih hingga kering di bawah sinar matahari selama 7 hari. Kemudian haluskan kulit talas yang sudah kering dengan blender dan diayak dengan ayakan 40 mesh. 
Jurnal Keilmuan dan Aplikasi Teknik

UNISTEK, 2019, Vol. 6, No.2

Proses delignifikasi bertujuan menghilangkan kandungan senyawa lignin pada serbuk kulit talas karena lignin akan menghambat proses hidrolisis. Tahapan pada proses delignifikasi dilakukan dengan menggunakan 70 gram serbuk kulit talas hasil pengayakan kemudian ditambahkan $\mathrm{NaOH}$ 1,5\%. Lakukan pemanasan dan pengadukan dengan hotplate dan magnetic stirrer selama 15 menit pada suhu $120^{\circ} \mathrm{C}$.

Pengamatan dilakukan pada bubur kulit talas dan terlihat terjadi perubahan warna menjadi warna hitam pekat. Pisahkan residu dengan larutannya kemudian cuci residu dengan aquades untuk mendapatkan $\mathrm{pH}$ netral. Setelah $\mathrm{pH}$ mencapai netral, keringkan residu menggunakan oven dengan suhu $100^{\circ} \mathrm{C}$. Kemudian ayak kembali residu yang telah kering dengan ukuran 40 mesh. Proses ini dilakukan sebanyak tiga kali untuk menghilangkan lignin dengan sempurna.

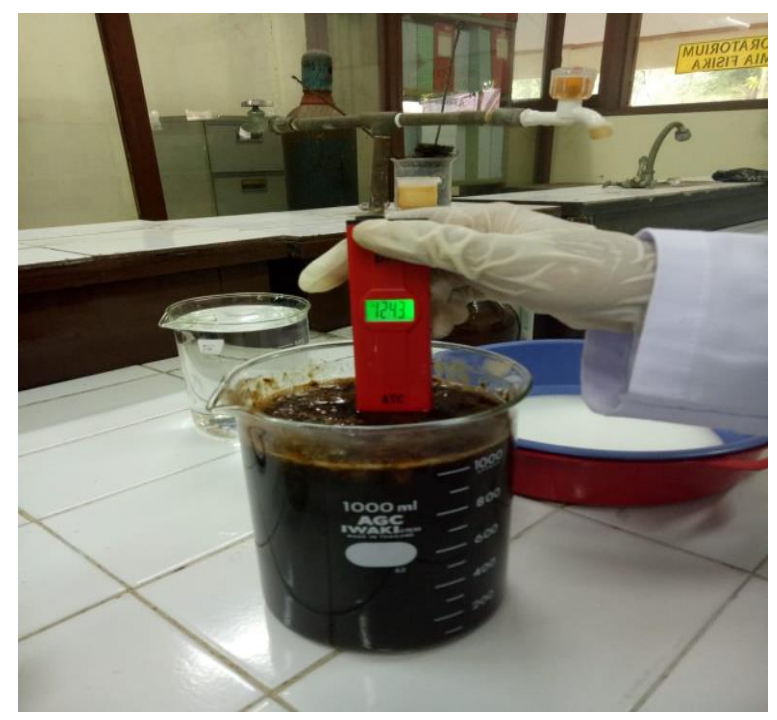

Gambar 2. Proses Delignifikasi

\subsection{Hidrolisis dan Fermentasi}

Sebanyak 30 gram serbuk hasil delignifikasi ditambahkan aquades dan $\mathrm{HCl} 10 \%$ kemudian dipanaskan menggunakan alat hidrolisa selama 2 jam pada suhu $100^{\circ} \mathrm{C}$. Kemudian saring larutan yang sudah dihidrolisis dengan kertas saring. Proses ini dilakukan secara triplo.

Berikut persamaan reaksi hidrolisis :

$\left(\mathrm{C}_{5} \mathrm{H}_{10} \mathrm{O}_{5}\right) \mathrm{n}+\mathrm{nH}_{2} \mathrm{O} \longrightarrow \mathrm{C}_{6} \mathrm{H}_{12} \mathrm{O}_{6}$
Selanjutnya dilakukan proses fermentasi pada kondisi $\mathrm{pH}$ 4,5 dengan cara menambahkan $\mathrm{NaOH}$. Sebanyak $50 \mathrm{~mL}$ filtrat dimasukkan ke dalam botol kaca , kemudian tambahkan ragi tape yang sudah dihaluskan seberat 7 gram, tutup rapat botol kaca. Lakukan tahap fermentasi dengan variasi waktu 4, 6, 8, 10, 12 hari.

Fermentasi glukosa oleh yeast saccharomyces ceraviceae akan menghasilkan etanol dan karbon dioksida melalui reaksi sebagai berikut.

$$
\begin{aligned}
& \mathrm{C}_{6} \mathrm{H}_{12} \mathrm{O}_{6} \stackrel{\text { yeast }}{\text { glukosa }} \\
& \begin{array}{l}
\mathrm{C}_{2} \mathrm{H}_{5} \mathrm{OH} \\
\text { etanol }
\end{array}
\end{aligned}
$$

\subsection{Proses Distilasi}

Destilasi adalah proses pemisahkan campuran dua atau lebih zat cair ke dalam fraksi-fraksinya berdasarkan titik didihnya. Distilasi terhadap hasil fermentasi dilakukan pada titik didih etanol yaitu $78^{\circ} \mathrm{C}$. Kemudian hasil distilasi dilakukan uji nyala dan penentuan berat jenis.

\subsection{Pembahasan}

Dari hasil uji nyala didapatkan hasil positif dan berat jenis didapatkan berat jenis larutan adalah $0,848 \mathrm{gr} / \mathrm{mL}$ dimana berat jenis etanol adalah $0,789 \mathrm{gr} / \mathrm{mL}$, hasilnya menunjukan nilai yang mendekati, perbedaan ini dapat disebabkan oleh kemungkinan belum murninya hasil destilasi.

Pada penelitian konversi limbah kulit talas Bogor menjadi bioethanol ini didapatkan yield sebesar 14,68 \% memperlihatkan bahwa limbah ini memiliki potensi sebagai sumber bioethanol dan terbuka potensi terhadap limbah-limbah organik lain untuk dikembangkan karena negara kita sangat banyak memproduksi limbah organik. Perlu dilakukan pengembangan metode yang lebih akurat dan efisien sehingga bisa diaplikasikan oleh banyak pihak dan menghasilkan yield yang lebih baik. Konversi biomassa ini akan 
Jurnal Keilmuan dan Aplikasi Teknik

UNISTEK, 2019, Vol. 6, No.2

sangat menarik untuk dikembangkan baik dari segi bahan baku limbahnya maupun dalam hal metode.

Penanggulangan limbah organik yang jumlahnya berbanding lurus dengan pertambahan jumlah penduduk Indonesia perlu metode penanganan yang inovatif dan efisien sehingga masalah limbah ini memiliki banyak solusi. Salah satunya pengolahan limbah organik dengan konversi biomassa menjadi bioetanol yang merupakan salah satu solusi penanggulangan yang menjanjikan untuk dikembangkan. Karena bioetanol merupakan bahan bakar alternatif yang ramah lingkungan.

\section{Kesimpulan}

Konversi biomassa limbah organik kulit talas Bogor sebagai bahan yang memiliki potensi sebagai sumber bahan bakar alternatif bioetanol yang kami teliti memperlihatkan hasil yang positif. Metode yang kami lakukan adalah dengan proses preparasi limbah menjadi serbuk, proses delignifikasi yakni untuk menghilangkan lignin yang merupakan senyawa yang memiliki potensi menghambat proses hidrolisis. Selanjutnya dilakukan proses hidrolisis yang berfungsi memecah polisakarida yaitu selulosa dan hemiselulosa menjadi monomer gula seperti glukosa, pentose dan heksosa yang nantinya akan dikonversi pada proses fermentasi menjadi bioetanol. Proses fermentasi digunakan ragi tape didapatkan hasil optimum pada hari ke 6. Penelitian ini menghasilkan destilat hasil penyulingan yaitu $79 \mathrm{~mL}$ bioetanol (berat jenis destilat $0,8483 \mathrm{gr} / \mathrm{mL}$ dengan yield $14,68 \%$. Dengan demikian limbah kulit talas Bogor memiliki potensi menjadi sumber bahan bakar alternatif bioetanol.

\section{Daftar Pustaka}

Arlianti, Lily., Bioetanol Sebagai Sumber Green Energy Alternatif yang Potensial di Indonesia, Jurnal UNISTEK, Januari 2018, Edisi 5 no. 1 .
Fessenden \& Fessenden, Kimia Organik, Jakarta: Erlangga, 1994

Pinus Lingga(dkk), Bertanam Umbi-umbian, Jakarta : Swadaya, 1992

Devarapalli, Mamatha \& Hasan k.Atiyeh., Review paper : A Review of Conversion processes for bioethanol production with a focus on syngas fermentation, Biofuel Research Journal, 2015, volume 7, pp 268280.

Hossain, et.al.,, Bioethanol Fuel Production From Rotten Banana as an environmental waste management and suistainable energy, African Journal Microbiology Research, 2011, volume 5(6).pp 586-598

Judoamidjojo, R.M., E.G Said dan L. Hartoto, . Biokonversi. Bogor:PAU Bioteknologi IPB, 1989

Setyawati, Harimbi dan Nanik A.Rahman, Bioetanol Dari Kulit Nanas dengan Variasi Massa Saccharomyces Cereviceae Dengan Waktu Fermentasi, Malang: Journal ITN

Putra, Dian Asmoro dkk, Energi Alternatif Biogas dari Kulit Buah Coklat, Jogjakarta : jurnal jurusan Teknik Kimia UPN

Oktavia, M., Produksi Bioetanol Dari Tongkol Jagung Dengan Metoda Simultan Sakarifikasi Dan Fermentasi. Andalas : Jurnal Kimia Unand (ISSN No. 23033401), 1 Maret 2014, Volume 2 Nomor 1. 